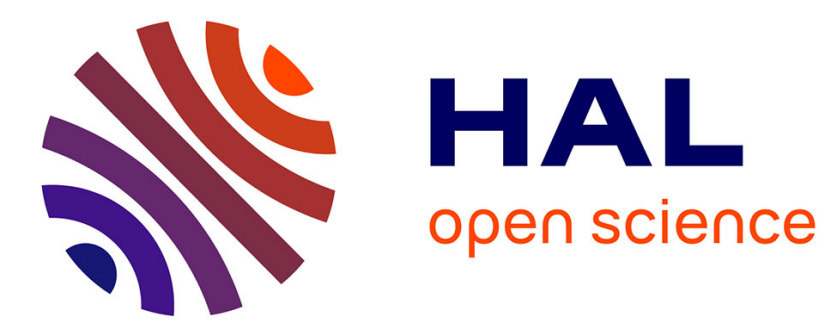

\title{
Cardboard proportions and total solids contents as driving factors in dry co-fermentation of food waste
}

Gabriel Capson-Tojo, Eric Trably, Maxime Rouez, Marion Crest, Nicolas Bernet, Jean-Philippe Steyer, Jean-Philippe Delgenès, Renaud Escudié

\section{- To cite this version:}

Gabriel Capson-Tojo, Eric Trably, Maxime Rouez, Marion Crest, Nicolas Bernet, et al.. Cardboard proportions and total solids contents as driving factors in dry co-fermentation of food waste. Bioresource Technology, 2018, 248, pp.229-237. 10.1016/j.biortech.2017.06.040 . hal-02621022

\author{
HAL Id: hal-02621022 \\ https://hal.inrae.fr/hal-02621022
}

Submitted on 26 May 2020

HAL is a multi-disciplinary open access archive for the deposit and dissemination of scientific research documents, whether they are published or not. The documents may come from teaching and research institutions in France or abroad, or from public or private research centers.
L'archive ouverte pluridisciplinaire HAL, est destinée au dépôt et à la diffusion de documents scientifiques de niveau recherche, publiés ou non, émanant des établissements d'enseignement et de recherche français ou étrangers, des laboratoires publics ou privés. 


\section{Accepted Manuscript}

Cardboard proportions and total solids contents as driving factors in dry cofermentation of food waste

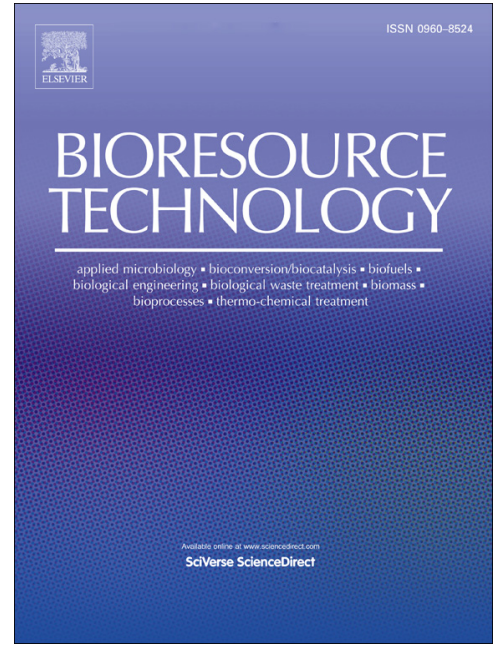

Gabriel Capson-Tojo, Eric Trably, Maxime Rouez, Marion Crest, Nicolas Bernet, Jean-Philippe Steyer, Jean-Philippe Delgenès, Renaud Escudié

PII: S0960-8524(17)30927-6

DOI: http://dx.doi.org/10.1016/j.biortech.2017.06.040

Reference: BITE 18277

To appear in:

Bioresource Technology

Received Date:

27 April 2017

Revised Date:

6 June 2017

Accepted Date:

7 June 2017

Please cite this article as: Capson-Tojo, G., Trably, E., Rouez, M., Crest, M., Bernet, N., Steyer, J-P., Delgenès, JP., Escudié, R., Cardboard proportions and total solids contents as driving factors in dry co-fermentation of food waste, Bioresource Technology (2017), doi: http://dx.doi.org/10.1016/j.biortech.2017.06.040

This is a PDF file of an unedited manuscript that has been accepted for publication. As a service to our customers we are providing this early version of the manuscript. The manuscript will undergo copyediting, typesetting, and review of the resulting proof before it is published in its final form. Please note that during the production process errors may be discovered which could affect the content, and all legal disclaimers that apply to the journal pertain. 


\title{
Cardboard proportions and total solids contents as driving factors in dry co-fermentation of food waste
}

\author{
Gabriel Capson-Tojo ${ }^{1,2}$, Eric Trably ${ }^{1}$, Maxime Rouez $^{2}$, Marion Crest $^{2}$, Nicolas Bernet ${ }^{1}$, Jean-
} Philippe Steyer ${ }^{1}$, Jean-Philippe Delgenès ${ }^{1}$, Renaud Escudié ${ }^{1, *}$

1. LBE, INRA, 102 avenue des Etangs, 11100, Narbonne, France

2. Suez, CIRSEE, 38 rue du Président Wilson, 78230, Le Pecq, France

* Corresponding author: tel. +33 (0) 468.425.173, e-mail: renaud.escudie@inra.fr

\begin{abstract}
This study evaluated the influence of the co-substrate proportions (0-60\% of cardboard in dry basis) and the initial total solid contents $(20-40 \%)$ on the batch fermentation performance. Maximum hydrogen yields were obtained when mono-fermenting food waste at high solids contents $\left(89 \mathrm{ml} \mathrm{H}_{2} \cdot \mathrm{gVS}^{-1}\right)$. The hydrogen yields were lower when increasing the proportions of cardboard. The lower hydrogen yields at higher proportions of cardboard were translated into higher yields of caproic acid (up to $70.1 \mathrm{gCOD} \cdot \mathrm{kgCOD}_{\text {bio }}{ }^{-1}$ ), produced by consumption of acetic acid and hydrogen. The highest substrate conversions were achieved at low proportions of cardboard, indicating a stabilization effect due to higher buffering capacities in cofermentation. Clostridiales were predominant in all operational conditions. This study opens up new possibilities for using the cardboard proportions for controlling the production of high added-value products in dry co-fermentation of food waste.
\end{abstract}

\section{Keywords}

Biohydrogen; Biorefinery; High solids; Dark fermentation; Mixed culture 


\section{Introduction}

The production of food waste (FW) is currently an issue of global importance. This biowaste represents one third of the total food generated for human consumption, accounting for 1.3 billion tons of waste every year (FAO, 2012). In addition, the economic and population growth will cause an increase in the production of urban $\mathrm{FW}$, which is expected to raise by $44 \%$ from 2005 to 2025 (Melikoglu et al., 2013). The traditional treatment techniques for FW, mainly landfilling and incineration, lead to several environmental issues, such as leaching, emission of greenhouse gases and odor production. Moreover, the costs associated with these practices are expected to increase in the coming years.

Therefore, it is necessary to develop and optimize technologies that allow an efficient FW treatment, integrating its disposal with its valorization and recycling. In the context of a rising global energy demand, the development of clean and renewable energy sources is a mayor goal to be achieved in the future. The production of hydrogen and volatile fatty acids (VFAs) by dark fermentation (DF) of FW is a promising alternative that can serve for both purposes: (i) FW treatment and (ii) generation of renewable energy (hydrogen) and carbon sources (VFAs). Hydrogen is a carbon-free clean fuel with a high energy content $\left(122 \mathrm{~kJ} \cdot \mathrm{g}^{-1}\right)$. It can be used for electricity production, in direct combustion or for the synthesis of chemicals (Ghimire et al., 2015). The concomitant VFAs produced during DF are a renewable carbon source that can be used for several purposes and that have high added-value in some cases (i.e. caproic acid).

Mixed VFAs from FW have been applied for production of electricity (Y. Chen et al., 2013), production of biogas or biodiesel (Fontanille et al., 2012), biological nutrient removal (Lim et al., 2000) and for the synthesis of value-added chemicals, such as ethanol (Kiran et al., 2015), yeast flavor (Mantzouridou et al., 2015), long-chain fatty acids (Pleissner et al., 2015) or polyhydroxyalkanoates (H. Chen et al., 2013). Among the options for hydrogen and VFA production, DF has low energy requirements, it is environmentally friendly, it has high hydrogen production rates and it can accommodate a great variety of substrates (Dahiya et al., 
2015; Kim et al., 2014; Wang et al., 2014).

FW has a relatively high total solids (TS) content ( 20\%), with around $90 \%$ corresponding to volatile solids (VS). These VS correspond mainly to easily degradable carbohydrates (50-70\%) (Uçkun Kiran et al., 2014). These characteristics make FW a very suitable substrate for DF, mainly because the hydrogen yields obtained by DF have been found to be correlated with the contents of carbohydrate in the substrates (Guo et al., 2014). Moreover, the high TS content of FW allows the operation under dry conditions (20-40\% TS), which requires smaller reactor volumes and produces less digestate than wet DF. However, FW also contains proteins (15-25 $\%)$ and lipids (13-30\%), components which may jeopardize the process. The high protein proportions may cause nutrient imbalance due to a low $\mathrm{C} / \mathrm{N}$ ratio. Another issue that may appear during DF is a drop in the $\mathrm{pH}$ of the reactors due to accumulation of VFAs, leading to production of lactate or ethanol and thus decreasing the hydrogen yields. To avoid these problems, the addition of another substrate for co-fermentation with FW has been applied to balance nutrients (i.e., increase $\mathrm{C} / \mathrm{N}$ ratio) and to provide buffering capacity (e.g. by slowing down acid accumulation or by directly increasing the alkalinity). Boni et al. (2013) effectively co-fermented FW with slaughterhouse waste to provide buffering capacity, obtaining hydrogen yields up to $145 \mathrm{ml} \mathrm{H}_{2} \cdot \mathrm{g} \mathrm{VS}^{-1}$ (compared to $74 \mathrm{ml} \mathrm{H}_{2} \cdot \mathrm{g} \mathrm{VS}^{-1}$ of $\mathrm{FW}$ alone). Waste sludge has also been used as an effective co-substrate for FW DF, stabilizing the hydrogen production by adjusting the $\mathrm{C} / \mathrm{N}$ ratio of the substrate and by providing buffer capacity (Kim et al., 2011; Sreela-or et al., 2011b; Zhou et al., 2013). Lime mud and white mud, from paper-making and ammonia-soda processes, respectively, have also led to synergistic effects when co-fermented with FW (Zhang et al., 2013; Zhang and Wang, 2013) due to an increased buffering capacity and an enhanced macronutrients balance. Recently, Zheng et al. (2017) co-fermented Sophora flavescens residues (a medicinal plant) and FW for production of lactic acid, achieving high conversions by balancing the $\mathrm{C} / \mathrm{N}$ ratio and the $\mathrm{pH}$. In addition, Pagliaccia et al. (2016) codigested FW with olive husks for hydrogen production, observing synergetic effects and 
obtaining hydrogen yields up to $87 \mathrm{ml} \mathrm{H}_{2} \cdot \mathrm{g} \mathrm{VS}^{-1}$.

Due to its high $\mathrm{C} / \mathrm{N}$ ratio, its relatively slow biodegradability and its high TS content, an interesting option for dry co-fermentation with FW is cardboard waste (CB). In addition, FW and CB (which may account for up to $37 \%$ of the total municipal waste) are usually the main organic solid waste streams in urban areas, which makes CB an appropriate option for centralized DF with FW in those regions (Hogg et al., 2002; Kim and Oh, 2011; Zhang et al., 2012).

Therefore, the aim of this study was to evaluate the feasibility of FW dry DF with CB as cosubstrate for production of hydrogen and VFAs. The influence of the proportions of CB in the substrate and the initial TS contents on the performance of batch DF was investigated. Special attention was paid to the influence of these parameters on the final yields of the different metabolites obtained and to the structures of the microbial communities after fermentation.

\section{Materials and methods}

\subsection{Substrate and microbial inoculum}

A synthetic FW was prepared according to the VALORGAS report (VALORGAS, 2010). In agreement with this document, the main components of the FW were: fruits and vegetables (78 $\%)$, meat $(8.2 \%)$, bread $(6.2 \%)$, cereals $(4.8 \%)$, dairy products $(1.8 \%)$ and snacks $(1.5 \%)$. A more precise composition of the substrate can be found elsewhere (Capson-Tojo et al., 2017).

To ensure its homogeneity, the mixture was milled and blended. Compact cardboard (branded “'Cartonnages Michel') ') with a density of $1.42 \mathrm{~kg} \cdot \mathrm{m}^{-3}$ was used as co-substrate. It was shredded to less than $1 \mathrm{~mm}$ before its usage.

The inoculum was a mixture of two different sludges: (i) centrifuged granular sludge from a mesophilic industrial UASB reactor treating effluents from a sugar factory and (ii) a dried digestate (at $105^{\circ} \mathrm{C}$ for $24 \mathrm{~h}$; sieved at $1 \mathrm{~cm}$ ) from a thermophilic industrial plant treating the organic fraction of municipal solid waste. This latter digestate was added to increase the initial 
TS content of the inoculum. This allowed working at high initial TS contents in the reactors (up to $40 \%$ ). Both sludges were mixed in a proportion 1:2 (wet weight basis), obtaining a final TS content of $70.78 \%$ (70.85\% VS/TS).

\subsection{Batch dry dark co-fermentation}

The specific conditions of the experiments, as well as the particular objectives of the experimental set-up, are presented in Table 1.

The first three conditions $\left(\mathrm{FW}^{20-30 \%}\right)$ were fed with $\mathrm{FW}$ as sole substrate at three different $\mathrm{TS}$ contents (control reactors). The next four conditions $\left((\mathrm{FW}+\mathrm{CB})^{25-40 \%}\right)$ were defined to study the application of CB to increase the initial TS content of the substrate from 25 to $40 \%$. Depending on the TS content, the proportion of $\mathrm{CB}$ in the co-fermentation reactors ranged between 18 and $60 \%$ in dry basis. Finally, the complementary reactors $\left(\left(\mathrm{FW}+\mathrm{CB}+\mathrm{H}_{2} \mathrm{O}^{25-35 \%}\right)\right)$ were designed to differentiate the influence of the TS content on the DF performance from that of the CB \% in the substrate. These reactors had the same $\mathrm{CB}$ proportions than reactors $(\mathrm{FW}+\mathrm{CB})^{30-40 \%}$ but lower TS contents (the same of $\left.(\mathrm{FW}+\mathrm{CB})^{25-35 \%}\right)$. All the reactors were run with a substrate to inoculum $(\mathrm{S} / \mathrm{X})$ ratio of $0.25 \mathrm{~g} \mathrm{VS} \cdot \mathrm{g} \mathrm{VS}^{-1}$. After adding $60 \mathrm{~g}$ of $\mathrm{FW}$ into the vessels, the respective amounts of $\mathrm{CB}$, sludge and distilled water (according to Table 1) were supplemented and the mixture was thoroughly homogenized. The volume of the headspace was determined by measuring the difference in pressure after addition of a known volume of gas. The reactors were sealed and flushed with nitrogen to ensure anaerobic conditions. The incubation was carried out at $35^{\circ} \mathrm{C}$ and lasted for a period of 83 days. The glass reactors used had a total volume of 2.51 , with working volumes ranging from 280 to $540 \mathrm{ml}$ (according to the added amounts of sludge and CB). As described in Motte et al. (2015), the reactors used allowed sampling of the sludge during the fermentation process, avoiding disturbances of the headspace. The reactors had a specifically designed ball valve in their heads that allowed the introduction of a sampling device. After digestate collection, the system also permitted flushing out with nitrogen the small amounts of air that could have contacted the closed valve through 
the sampling device. This way, we ensured that minimal amounts of oxygen could enter the reactors. All the conditions were run in duplicate. In order to allow unbiased comparisons between the different conditions, the substrate concentrations shown in Table 1 were calculated according to the biodegradable $\mathrm{COD}\left(\mathrm{COD}_{\text {bio }}\right)$ added initially. This value was estimated from the experimental biochemical methane potentials (BMPs) of the substrates. The COD transformed into methane in the BMPs was assumed to be the fraction of biodegradable COD in the substrates.

\subsection{Analytical methods}

\subsubsection{Physicochemical characterization of the substrates}

The TS and VS contents were determined according to the standard methods of the American Public Health Association (APHA, 2005). The substrates were hydrolyzed with sulfuric acid for measurement of the protein and carbohydrates concentrations by the modified Lowry method (Lowry, 1951) and the Dubois method (Dubois et al., 1956), respectively. A gravimetric method (APHA, 2005) based on accelerated solvent extraction using an $\mathrm{ASE}^{\circledR} 200$, DIONEX coupled to a MULTIVAPOR P-12, BUCHI with heptane as solvent $\left(100 \mathrm{bar}, 105{ }^{\circ} \mathrm{C}\right.$, 5 cycles of 10 min static and 100s purge) was used to determine the lipid contents. The concentrations of Total Kjeldahl nitrogen (TKN) and ammonia nitrogen were measured with an AutoKjehdahl Unit K-370, BUCHI. Total organic carbon (TOC) and inorganic carbon (IC) were determined using a Shimadzu TOC-V $\mathrm{V}_{\mathrm{CSN}}$ Total Organic Carbon Analyzer coupled to a Shimadzu ASI-V tube rack. The total carbon (TC) was calculated as the sum of TOC and IC. The $\mathrm{pH}$ was measured by a WTW pHmeter series inoLab pH720. The chemical oxygen demand (COD) was analyzed using an Aqualytic 420721 COD Vario Tube Test MR (0-1500 $\left.\mathrm{mg} \cdot \mathrm{l}^{-1}\right) .2 \mathrm{ml}$ of sample were pipetted into each tube and then they were placed inside a HACH COD reactor at $150{ }^{\circ} \mathrm{C}$ for $2 \mathrm{~h}$. The COD concentrations were determined using an Aqualytic MultiDirect spectrophotometer.

\subsubsection{Biogas quantification and analysis}


The volume and composition of the biogas generated were determined as described in Cazier et al. (2015). The volumes of gas are expressed in normal conditions (at $0{ }^{\circ} \mathrm{C}$ and $1013 \mathrm{hPa}$ ) and the yields are expressed per gram of $\mathrm{COD}_{\text {bio }}$ added initially. A blank reactor was used to determine the amount of gas produced by endogenous respiration.

\subsubsection{Analysis of fermentation products}

The concentrations of the different metabolic products, i.e. VFAs, ionic species, lactic acid or ethanol, among others, were measured according to Motte et al. (2013). The concentration of free ammonia nitrogen (FAN) was calculated as a function of temperature, $\mathrm{pH}$, and concentration of total ammonia nitrogen (TAN), according to Rajagopal et al. (2013). As for the gas yields, in order to make the yields of final metabolites comparable between the different substrates, they were expressed per gram of $\mathrm{COD}_{\text {bio }}$ of substrate fed.

\subsection{Microbial analysis}

Samples of the initial inoculum and from the batch reactors at the end of the fermentation experiments were analyzed. Polymerase Chain Reaction (PCR), quantitative PCR (qPCR) and DNA sequencing techniques were used. A precise description of the methodology employed can be found elsewhere (Moscoviz et al., 2016).

\subsection{Data analysis}

The least squares method was applied to study linear correlations between variables. Principal component analyses (PCA) were performed to analyze the relationships between fermentation products of the DF. The PCAs were carried out using the software package mixOmics in R. In addition, a dual hierarchal clustering analysis was used to study the results from metagenomics. The statistical analyses were computed using the statistical software R 3.2.5 (The R Foundation for Statistical Computing, Vienna, Austria). In addition, it must be mentioned that the errors bars shown in Figure 1, as well as the errors presented in Tables 1 and 2, correspond to the standard deviations of the experimental results. 


\section{Results and discussion}

\subsection{Characterization of substrates}

The main characteristics of the substrates are presented in Table 2.

The results for the synthetic FW were similar to those reported in the literature (Capson-Tojo et al., 2016). It was mainly composed of carbohydrates $\left(697 \mathrm{~g} \cdot \mathrm{kg} \mathrm{TS}^{-1}\right)$ and it had relatively high contents of TS $(21.6 \%)$, of which $96.2 \%$ corresponded to VS. The results for the CB suggest that it is a suitable co-substrate for FW dry DF. In this context, CB can be used to increase the $\mathrm{C} / \mathrm{N}$ ratio and the TS content of the substrate. In addition, it can also supply alkalinity to the system. A more extensive characterization of the substrates can be found in Capson-Tojo et al. (2017).

\subsection{Performance of the dry anaerobic co-fermentation reactors}

As it can be observed in Table 3, different products, as well as different total substrate conversions, were obtained. The substrate conversions and the product yields were calculated by dividing the sum of the products obtained at the end of the experiment (in COD units) by the $\mathrm{COD}_{\text {bio }}$ added initially. In order to avoid accounting twice for the COD corresponding to hydrogen production-consumption, the hydrogen yields presented correspond only to the volumes of hydrogen removed from the reactors.

The achieved substrate conversions were high for a DF process, ranging from 565 to $698 \mathrm{~g}$ $\mathrm{COD} \cdot \mathrm{kg} \mathrm{COD}_{\mathrm{bio}}{ }^{-1}$. The substrate conversions varied slightly, mainly due to the substrate composition. The reactors fed with the same substrate showed very close conversions $(e . g$. $\mathrm{FW}^{20-30 \%}$, with values of 620-631 $\mathrm{g} \mathrm{COD} \cdot \mathrm{kg} \mathrm{COD}_{\text {bio }}{ }^{-1}$ ). Interestingly, the highest substrate conversions were obtained in the reactors fed with a mixture of $36 \%$ of $\mathrm{CB}$ (i.e. $(\mathrm{FW}+\mathrm{CB})^{30 \%}$ and $\left.\left(\mathrm{FW}+\mathrm{CB}+\mathrm{H}_{2} \mathrm{O}\right)^{25 \%}\right)$, observing a synergy when this co-substrate was added. A possible explanation for the higher conversions may be that when adding small amounts of CB to the substrate, the initial substrate concentration is diluted (see Table 1). In addition, CB may have acted as buffer. Therefore, small quantities of CB added to the substrate may avoid or slow 
down the $\mathrm{pH}$ drop during the acidification process, allowing longer and more extended fermentations. This hypothesis was supported by the final $\mathrm{pH}$ values in reactors (Figure $1 \mathrm{C}$ ), which were higher at low co-digestion ratios. Moreover, while in reactors with higher initial FW concentrations (such as $\left(\mathrm{FW}+\mathrm{CB}^{25 \%}\right)$ ) significant lactic acid peaks were observed initially (data not shown), the maximum concentration of this acid (which may act as sign for acidification due to overloading) was much lower, and even negligible, in reactors fed with higher CB proportion.

In addition, the conversions were higher in the water supplemented reactors $\left(\mathrm{FW}+\mathrm{CB}+\mathrm{H}_{2} \mathrm{O}^{25-}\right.$ ${ }^{35 \%}$ ), suggesting that the addition of water to the reactors (i.e. working at lower TS contents) may have favored the DF process due to lower VFA concentrations at lower TS contents.

\subsubsection{Effect of the operational parameters on the hydrogen production}

Figures 1A and 1B show the obtained hydrogen yields. As it can be observed, high hydrogen yields were achieved, with a maximum of $62.8 \mathrm{ml} \mathrm{H}_{2} \cdot \mathrm{g} \mathrm{COD}_{\text {bio }}{ }^{-1}$ (corresponding to $46.9 \mathrm{~g}$ $\mathrm{COD} \cdot \mathrm{g} \mathrm{COD}_{\text {bio }}{ }^{-1}$ and $89 \mathrm{ml} \mathrm{H}_{2} \cdot \mathrm{g} \mathrm{VS}^{-1}$ ) in mono-digestion of $\mathrm{FW}$ at $30 \% \mathrm{TS}\left(\mathrm{FW}^{30 \%}\right)$. This value agrees with those found in the literature, suggesting an efficient DF performance (Ghimire et al., 2015). Different maximum hydrogen yields within the range of the results presented in this study have been reported under different conditions, such as $87 \mathrm{ml} \mathrm{H}_{2} \cdot \mathrm{g} \mathrm{VS}^{-1}$ (Pagliaccia et al., 2016) when co-fermenting FW and olive-husks, $105 \mathrm{ml} \mathrm{H}_{2} \cdot \mathrm{g} \mathrm{VS}^{-1}$ after optimization of mono-digestion with buffer addition (Sreela-or et al., 2011a), $101 \mathrm{ml} \mathrm{H}_{2} \cdot \mathrm{g} \mathrm{VS}^{-1}$ for FW co-fermentation with sludge (Sreela-or et al., 2011b) or $145 \mathrm{ml} \mathrm{H}_{2} \cdot \mathrm{g} \mathrm{VS}^{-1}$ when cofermenting FW with slaughterhouse waste (Boni et al., 2013).

As shown in Figure 1A, the hydrogen yields were affected linearly by the TS contents. However, while these values increased with the TS content in the mono-digestion systems (49.5-62.8 $\mathrm{ml} \mathrm{H}_{2} \cdot \mathrm{g} \mathrm{COD}_{\text {bio }}{ }^{-1}$ ), it was negatively correlated to the initial TS concentration in the co-digestion reactors (11.6-43.4 $\left.\mathrm{ml} \mathrm{H}_{2} \cdot \mathrm{g} \mathrm{COD}_{\text {bio }}{ }^{-1}\right)$. High TS contents have been found to reduce the hydrolysis rates with lignocellulosic biomass as substrate for DF, jeopardizing also 
the hydrogen yields (Motte et al., 2013). Nevertheless, the decrease in the hydrogen yields observed in the co-digestion systems cannot be attributed to the TS content only. As it can be observed in Figure 1B, the hydrogen yields were similar in the reactors fed with the same substrate (same CB proportion in the substrate) regardless the initial TS content. Therefore, it can be stated that the addition of CB affected negatively the obtained hydrogen yields. The main reason for that is the recalcitrant lignocellulosic biomass present in the $\mathrm{CB}$. The carbohydrates in CB are mainly cellulose, hemicellulose and lignin, which are less biodegradable than those found in FW. When compared to FW, the hydrolysis of the organic matter in CB occurred at a much lower extent and was much slower. Therefore, the organic matter present in the $\mathrm{CB}$ did not contribute significantly to the hydrogen yields during the first days of DF, when hydrogen production took place.

A possible explanation for the increasing hydrogen yields at higher TS contents in the monodigestion reactors might be that the high initial TS contents limited to some extent the hydrolysis kinetics. This might have slowed down the production of acids and avoided a more pronounced $\mathrm{pH}$ drop besides the lower water content at the beginning of $\mathrm{DF}$ (when hydrogen is produced). In fact, the minimum $\mathrm{pH}$ values in the mono-digestion reactors (after 10 days) did not differ significantly (5.38-5.45). Therefore, even if the VFA concentrations were higher at greater TS contents (up to $36.5 \mathrm{~g} \mathrm{COD} \cdot 1^{-1}$ in $\mathrm{FW}^{30 \%}$ ), the higher TS contents (and consequent lack of water) acted as buffer, which avoided a decrease in the $\mathrm{pH}$. This hypothesis is supported also by the $\mathrm{pH}$ values in the co-fermentation reactors. In those systems, even if the hydrogen yields were similar at the same co-digestion ratios, lower $\mathrm{pH}$ values were reported at lower TS contents (see $\left(\mathrm{FW}+\mathrm{CB}^{20-40 \%}\right)$ vs. $\left(\mathrm{FW}+\mathrm{CB}+\mathrm{H}_{2} \mathrm{O}^{25-25 \%}\right)$ in Figure 1C). Wang et al. (2015) also observed increasing hydrogen yields at increasing TS contents under semi-dry conditions (maximum at $13 \% \mathrm{TS}$ ), obtaining maximum yields of $148.9 \mathrm{ml} \mathrm{H}_{2} \cdot \mathrm{g} \mathrm{VS}^{-1}$ during $\mathrm{FW}$ monodigestion with an adjusted $\mathrm{pH}$ of 6.0. The maximum yield reported by Wang et al. (2015) was higher than ours $\left(89 \mathrm{ml} \mathrm{H}_{2} \cdot \mathrm{g} \mathrm{VS}^{-1}\right)$. However, it must be considered that in their experiment 
they aimed to optimize the DF conditions for hydrogen production (the $\mathrm{pH}$ was controlled and the working TS contents were much lower), which was not the objective of this study.

\subsubsection{Effect of the operational parameters on the production of volatile fatty acids}

As shown in Table 3, high VFA yields were obtained, with values for the total VFAs ranging from 557 to $675 \mathrm{~g} \mathrm{COD} \cdot \mathrm{kg} \mathrm{COD}$ bio $^{-1}$. As for the substrate conversions, the yields of total VFAs depended mainly on the composition of the substrate, with similar values for the monodigestion reactors and the highest yields obtained when adding small amounts of CB. Again, lower values were observed at higher proportions of CB and higher TS contents. This parallelism exists because the main products were VFAs (mainly acetic and butyric acids) and therefore the substrate conversion and the yields of these acids were directly related.

The predominant VFAs were similar in all the reactors, with acetic and butyric acids being the mayor species, followed by caproic acid and finally by propionic and valeric acids. These values are in agreement with the literature. After phosphoric acid pretreatment of FW,

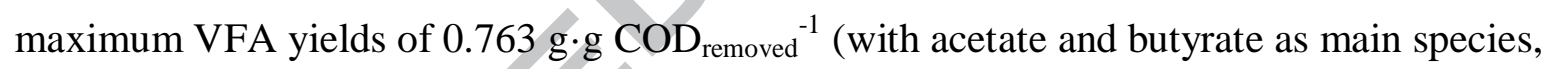
followed by propionate and traces of valerate) were achieved by Shen et al. (2016). In addition, at an initial $\mathrm{pH}$ of 10 , a maximum yield of $0.253 \mathrm{~g} \mathrm{COD} \cdot \mathrm{g} \mathrm{COD}_{\text {initial }}^{-1}$ (with acetate and butyrate as main species, followed by propionate and traces of valerate) has been reported (Dahiya et al., 2015). Also, an optimum of $0.918 \mathrm{~g} \cdot \mathrm{g} \mathrm{VSS}_{\text {removed }}^{-1}$ was obtained (with butyrate followed by acetate and propionate) by Wang et al. (2014) at an initial $\mathrm{pH}$ 6.0. When testing semi-dry conditions (around $13 \% \mathrm{TS}$ content as maximum), an optimum of $0.799 \mathrm{~g}$ COD.g $\mathrm{VS}^{-1}$ was achieved at low TS contents during FW mono-digestion when controlling the $\mathrm{pH}$ at 6.0 (propionate as main VFA, followed by butyrate, acetate and valerate) (Wang et al., 2015). In addition, hydrothermal pretreatment of FW led to improvements of the VFA yields, up to of $0.908 \mathrm{~g} \cdot \mathrm{g} \mathrm{VSS}_{\text {removed }}^{-1}$ (with butyrate followed by acetate, propionate and valerate) (Yin et al., 2014). Finally, when co-fermenting FW with waste activated sludge at optimal conditions, yields up to $0.670 \mathrm{~g} \mathrm{COD} \cdot \mathrm{g} \mathrm{VS}^{-1}$ have been achieved (acetic as main species, followed by 
propionic, butyric and valeric) by Chen et al. (2013).

Interestingly, this study shows a main difference with the others reported: the relatively high yields of caproic acid achieved (up to $70.1 \pm 5.7 \mathrm{~g} \mathrm{COD} \cdot \mathrm{g} \mathrm{COD}_{\mathrm{bio}}{ }^{-1}$ ). Other than the inoculum used and the operational conditions, this difference is likely to be a consequence of the fermentation time. While most of the studies dealing with FW DF last for short periods of time (i.e. 5-6 days maximum) or have short retention times, this experiment lasted for 83 days, which allowed an extensive fermentation to occur. As the production of caproate showed a lag phase (not observed for any other acid) of 5 days minimum (data not shown), much longer fermentation periods than those required for other acids must be applied to observe significant caproate biosynthesis using DF. This can be an interesting approach due to the high addedvalue of caproic acid when compared to other VFAs produced by DF. In an attempt to evaluate the relationships between the studied parameters (i.e. co-digestion ratio and TS content) and the final yields of the VFAs obtained, PCA analyses were carried out. The yields of final metabolites were expressed as g COD. $\mathrm{kg} \mathrm{COD}_{\mathrm{bio}}{ }^{-1}$ for the PCAs. As the behaviors were different in the mono-digestion and the co-digestion systems, two different analyses were performed. The obtained results are presented in Figure 2.

As it can be observed, two totally different behaviors were observed according to the substrate used (i.e. mono-digestion and co-digestion). This is because, while higher TS contents led to higher substrate $(\mathrm{FW})$ concentrations in the mono-digestion reactors, in the co-digestion systems it caused the opposite effect: the increasing TS contents were associated with more CB added, which caused lower initial FW concentrations (Table 1) and higher buffer capacities in the system.

Therefore, in the mono-digestion reactors (Figure 2A), the TS content was found to be negatively correlated to the valeric, caproic and acetic acids yields and positively correlated to the yields of butyric acid (with no correlation to the yield of propionic acid). Different conclusions can be extracted from these results. First of all, it must be mentioned that, as higher 
butyric acid yields and lower acetic acid yields were observed at higher TS, this means that the ratio butyric/acetic acid increased at high TS. This indicator can be used as an indicator of the stability of the DF process (Ghimire et al., 2015), with increasing values at lower $\mathrm{pH}$ and higher VFA concentrations. As it has already been mentioned, the final concentrations of VFAs increased with the TS, which probably caused a metabolic shift towards butyrate production due to product-induced inhibition at the relatively low working $\mathrm{pH}$ values $(5.50-5.54)$. In addition, as the increase of the butyric/acetic acid ratio did not cause lower hydrogen yields (actually the opposite occurred), it can also be concluded that the reaction of homoacetogenesis played a major role for hydrogen consumption-acetic acid production (Ghimire et al., 2015).

Higher initial TS contents (thus final VFA concentrations) also led to lower yields of caproic and valeric acids. This can also be explained by the negative effect of higher final concentrations of VFAs on the fermentation process.

On the other hand, in the co-fermentation systems (Figure 2B), the final yields of propionic, butyric and valeric acids were relatively not affected by the initial working conditions.

However, the initial working conditions clearly affected the yields of acetic and caproic acids. As mentioned before, in this case, the TS contents were adjusted by the amount of CB, so obviously the TS was negatively correlated to the FW:CB ratio. In addition, in Figure 2B a proportionality can be observed between the TS and final $\mathrm{pH}$ (in opposition with the FW: $\mathrm{CB}$ ratio), which also suggests the great buffering capacity of the $\mathrm{CB}$. Concerning to the yields of acetic acid, they were higher at lower proportions of CB in the substrates and lower TS contents (also in the mono-digestion reactors; see Figure 2A). Inversely, the yields of caproic acid were higher at higher proportions of CB in the substrates and higher TS contents, suggesting that both variables may have stimulated the synthesis of this added-value VFA. As high TS contents during FW mono-digestion did not lead to higher caproate yields, it can be hypothesized that the pathways of caproate formation were favored in the conditions were the $\mathrm{pH}$ was kept at high values (6.3-6.6) due to the increased buffer capacity related to addition of 
CB. In fact, the highest yields of caproic acid were obtained in the reactors with the highest proportions of $\mathrm{CB}\left(60 \% \mathrm{CB}\right.$ dry basis), with values of $70.1 \pm 5.6 \mathrm{~g} \mathrm{COD} \cdot \mathrm{kg} \mathrm{COD}_{\text {bio }}{ }^{-1}$ $(\mathrm{FW}+\mathrm{CB})^{40 \%}$ and $69.6 \pm 2.2 \mathrm{~g} \mathrm{COD} \cdot \mathrm{kg} \mathrm{COD}_{\mathrm{bio}^{-1}}\left(\mathrm{FW}+\mathrm{CB}+\mathrm{H}_{2} \mathrm{O}\right)^{35 \%}$.

Interestingly, other than been negatively correlated to the yields of acetic acid, the yields of caproic acid were also negatively related to the maximum hydrogen yields obtained $\left(\mathrm{R}^{2}\right.$ of 0.894 for the reactors $(\mathrm{FW}+\mathrm{CB})^{25-40 \%}$ and of 0.972 for the reactors $\left.\left(\mathrm{FW}+\mathrm{CB}+\mathrm{H}_{2} \mathrm{O}\right)^{25-35 \%}\right)$. This suggests that caproic acid was synthetized by elongation of acetate, using hydrogen as electron donor (eq.1), as described in Steinbusch et al. (2011). Other than hydrogen, a common electron donor for caproate synthesis in mixed culture is ethanol (eq. 2) (Weimer et al., 2015). The following simplified reactions represent both pathways (Steinbusch et al., 2011; Weimer et al., 2015).

$$
\begin{aligned}
& 3 \mathrm{C}_{2} \mathrm{H}_{3} \mathrm{O}_{2}^{-}+2 \mathrm{H}^{+}+4 \mathrm{H}_{2} \rightarrow \mathrm{C}_{6} \mathrm{H}_{11} \mathrm{O}_{2}^{-}+4 \mathrm{H}_{2} \mathrm{O} \\
& \Delta \mathrm{G}^{0,}=-177 \mathrm{~kJ} \cdot \mathrm{mol}^{-1} \quad \text { Eq. } 1 \\
& \mathrm{C}_{2} \mathrm{H}_{3} \mathrm{O}_{2}{ }^{-}+2 \mathrm{C}_{2} \mathrm{H}_{6} \mathrm{O} \rightarrow \mathrm{C}_{6} \mathrm{H}_{11} \mathrm{O}_{2}^{-}+2 \mathrm{H}_{2} \mathrm{O} \quad \Delta \mathrm{G}^{0,}=-79 \mathrm{~kJ} \cdot \mathrm{mol}^{-1} \quad \text { Eq. } 2
\end{aligned}
$$

Thus, in order to verify that hydrogen (and not ethanol) was the main electron donor for caproate production, ethanol was added into the reactors with the highest yields of caproic acid after the fermentation. Following the approach presented in Grootscholten et al. (2013), this allowed to test if this alcohol was the limiting reactant. No further caproate production was observed after ethanol addition (data not shown), suggesting also that eq. 1 was the main pathway for producing caproic acid in the reactors.

Optimum conditions for caproate production have been found at controlled $\mathrm{pH}$ of 7 with Clostridium Kluyveri as main fermenter (Steinbusch et al., 2011). Thus, the higher pH values when adding CB could be an explanation for the higher yields of caproic acid at higher percentage of $\mathrm{CB}$. More research must be carried out to verify if there was also a substrateinduced effect increasing the yields of caproic acid when CB was added. However, as cellulosic materials have been found to be suitable substrates for caproic acid production (and not for hydrogen production) (Kenealy et al., 1995; Weimer et al., 2015), this could also explain the 
higher yields at higher CB contents.

\subsection{Microbial analysis after the co-fermentation}

To identify relationships and to facilitate the interpretation of the results from metagenomics, a dual hierarchal clustering analysis (Figure 3) was carried out, using the relative abundances of the main bacteria ( $\geq 5 \%$ ) as input data (Venkiteshwaran et al., 2016).

Clostridiales were the main bacteria in all the reactors (with abundances ranging from 78 to 90 $\%$ ), with only one main OTU corresponding to Enterobacteriales, probably due to traces of oxygen present in the reactors (Chatellard et al., 2016). Clostridium butyricum (OTU 1) was found to a predominant species in the reactors, with abundances ranging from 9 to $41 \%$. C. butyricum is a very common fermenter during DF, known to play a major role in the production of hydrogen, butyrate and acetate. Moreover, this microorganism did not form any cluster with others, suggesting that its growth was independent from other bacteria. Although the microbial populations were similar within the reactors, some differences were observed, which lead to the identification of three main clusters. The first cluster (upper part of the graph) included the conditions working at low TS contents (20-25\%) and with low proportions of CB or only fed with FW. In this cluster, $C$. butyricum was predominant, but also high relative abundances of OTUs 2 (Neglecta timonensis; 23-4\%) and 6 (Clostridium sporosphaeroides; 0-17\%) were identified. Both are also clostridia and belong within the same OTU cluster. The second cluster was formed by the reactors with initial TS contents of $30 \%$. In these conditions, C. butyricum was clearly predominant (much more than in the previous cluster), representing between 35 to $41 \%$ of the bacterial OTUs. Finally, the last cluster was formed by the reactors working at the highest TS contents (35-40\%). In those cases, even if $C$. butyricum was also a main species (9$17 \%)$, similar proportions of C. paraputrificum (8-16\%), E. cloacae (8-17\%) and L. massiliensis (9-10\%) (OTUs 4, 9 and 3 respectively; all in the same cluster) were also present. It is important to mention that these differences were not caused by a lack of bacterial growth in some conditions. The results of the qPCRs showed that significant amounts of bacterial $16 \mathrm{~S}$ 
copies were found in all the digestates, varying from $2.30 \cdot 10^{8} \pm 2.40 \cdot 10^{7}$ up to $4.88 \cdot 10^{10} \pm$ $3.32 \cdot 10^{9}$ copies $16 \mathrm{~S} \cdot \mathrm{g}^{-1}$.

All these results suggest that, other than the composition of the substrates, the TS content affected to some extent the structure of the microbial communities. In addition, the Shannon diversity index increased linearly with the TS contents $\left(\mathrm{R}^{2}\right.$ values of $0.729,0.828$ and 0.925 for reactors $\mathrm{FW}+\mathrm{CB}^{25-40 \%}, \mathrm{FW}+\mathrm{CB}+\mathrm{H}_{2} \mathrm{O}^{25-35 \%}$ and $\mathrm{FW}^{20-30 \%}$, respectively), with values ranging from 0.57 to 1.00 (data not shown). Therefore, more diverse ecosystems were observed at increasing TS contents. The influence of the TS content on the microbial communities and on population selection during DF has been previously reported. However, while previous authors presented $19 \%$ TS as a limit of operation for hydrogen production using wheat straw as substrate (Motte et al., 2014), in this study high hydrogen yields have been achieved at much more elevated TS contents (i.e. $30 \%$ TS) with FW as substrate. In addition, due to the low loads applied $\left(0.25 \mathrm{~g} \mathrm{VS} \cdot \mathrm{g} \mathrm{VS}^{-1}\right)$, excessive acidification of the reactors was avoided, favouring the growth of hydrogen-producing Clostridia over that of lactic acid bacteria even if high TS contents were used. Moreover, while the main bacterial species in the inoculum was found to be Bacilalles (data not shown), Clostridiales were the main species after fermentation in all the conditions. Thus, it can be stated that, while the substrate conversions and the hydrogen and VFA yields were mainly affected by the substrate composition, this was not the case for the final structure of the microbial communities, which were mainly influenced by the TS contents in the reactors. This suggests that the production of different metabolites was not determined by the growth of predominant bacteria, but rather by metabolic changes occurring within the same microbial species. This hypothesis deserves to be confirmed by carrying out further research. Finally, it must be mentioned that from all the different microorganisms known to produce caproic acid (i.e. C. Kluyveri, Eubacterium pyruvativorans or Rhodospirillum rubrum) (Angenent et al., 2016; Spirito et al., 2014), only C. Kluyveri was found in the reactors. However, while $C$. Kluyveri was predominant in other studies focused on caproate production 
from acetate (Steinbusch et al., 2011), this microorganism was a minority in our experiment, with relative abundances ranging from 0.25 to $0.71 \%$. Therefore, it was not possible to conclude that this microorganism was responsible for the production of caproic acid. In addition, in an attempt to find possible relationships between the main microbial OTUs and the obtained metabolic products, a correlation matrix was calculated with the relative abundances of the main OTUs, the substrate conversion and the metabolite yields as entries (data not shown). No significant relationships were found between the yields of caproic acid and any OTU. The follow-up of the fermentation process, including the DF dynamics (including both metabolites and populations), is an interesting approach that should be evaluated in the future to elucidate the microbial species (and the metabolic pathways) responsible for the obtained results. This would eventually allow driving the DF towards the production of the most interesting compounds.

\section{Conclusions}

Maximum hydrogen yields were obtained with $\mathrm{FW}$ at high TS contents $\left(62.8 \mathrm{mlH}_{2} \cdot \mathrm{gCOD}_{\mathrm{bio}}{ }^{-1}\right)$. CB addition caused lower hydrogen yields, but stabilized DF by increasing the buffering capacity, obtaining the highest substrate conversions at low proportions of $\mathrm{CB}$. The lower hydrogen yields when adding CB were translated into higher yields of caproic acid (up to 70.1 $\left.\mathrm{gCOD} \cdot \mathrm{kgCOD}_{\mathrm{bio}}{ }^{-1}\right)$, which was produced mainly by consumption of acetic acid and hydrogen. The microbial communities (with Clostridiales as main species) depended mainly on the TS contents. This study suggests that the FW/CB proportion can be used as an easy-to-control parameter for producing high added-value products.

\section{Acknowledgements}

The authors are thankful to Suez, which has financed this research under the CIFRE convention N²014/1146. In addition, the Communauté d'Agglomération du Grand Narbonne (CAGN) is 
also acknowledged for the financial support. Also Clémence Pages is gratefully acknowledged

for her assistance for starting the experiments.

\section{References}

1. Angenent, L.T., Richter, H., Buckel, W., Spirito, C.M., Steinbusch, K.J.J., Plugge, C.M., Strik, D.P.B.T.B., Grootscholten, T.I.M., Buisman, C.J.N., Hamelers, H.V.M., 2016. Chain Elongation with Reactor Microbiomes: Open-Culture Biotechnology to Produce Biochemicals. Environ. Sci. Technol., 50, 2796-2810.

2. APHA, 2005. Standard Methods for the Examination of Water and Wastewater. American Public Health Association, Washington, DC.

3. Boni, M.R., Sbaffoni, S., Tuccinardi, L., 2013. The influence of slaughterhouse waste on fermentative $\mathrm{H} 2$ production from food waste: preliminary results. Waste Manag. (New York, N.Y.), 33, 1362-71.

4. Capson-Tojo, G., Rouez, M., Crest, M., Steyer, J.-P., Delgenès, J.-P., Escudié, R., 2016. Food waste valorization via anaerobic processes: a review. Rev. Env. Sci. Biotechnol., 15, 499-547.

5. Capson-Tojo, G., Trably, E., Rouez, M., Crest, M., Steyer, J.-P., Delgenès, J.-P., Escudié, R., 2017. Dry anaerobic digestion of food waste and cardboard at different substrate loads, solid contents and co-digestion proportions. Bioresour. Technol., 233, $166-175$.

6. Cazier, E.A., Trably, E., Steyer, J.P., Escudie, R., 2015. Biomass hydrolysis inhibition at high hydrogen partial pressure in solid-state anaerobic digestion. Bioresour. Technol., 190, 106-113.

7. Chatellard, L., Trably, E., Carrère, H., 2016. The type of carbohydrates specifically selects microbial community structures and fermentation patterns. Bioresour. Technol., $221,541-549$.

8. Chen, H., Meng, H., Nie, Z., Zhang, M., 2013. Polyhydroxyalkanoate production from fermented volatile fatty acids: effect of $\mathrm{pH}$ and feeding regimes. Bioresour. Technol., $128,533-8$.

9. Chen, Y., Luo, J., Yan, Y., Feng, L., 2013. Enhanced production of short-chain fatty acid by co-fermentation of waste activated sludge and kitchen waste under alkaline conditions and its application to microbial fuel cells. Appl. Energy, 102, 1197-1204.

10. Dahiya, S., Sarkar, O., Swamy, Y. V, Mohan, S.V., 2015. Acidogenic fermentation of food waste for volatile fatty acid production with co-generation of biohydrogen. Bioresour. Technol., 182, 103-13.

11. Dubois, M., Gilles, K.A., Hamilton, J.K., Rebers, P.A., Smith, F., 1956. Colorimetric Method for Determination of Sugars and Related Substances. Anal. Chem., 28, 350 356.

12. FAO, 2012. Towards the future we want: end hunger and make the transition to sustainable agricultural and food systems. Rome.

13. Fontanille, P., Kumar, V., Christophe, G., Nouaille, R., Larroche, C., 2012. Bioconversion of volatile fatty acids into lipids by the oleaginous yeast Yarrowia 
lipolytica. Bioresour. Technol., 114, 443-9.

14. Ghimire, A., Frunzo, L., Pirozzi, F., Trably, E., Escudie, R., Lens, P.N.L., Esposito, G., 2015. A review on dark fermentative biohydrogen production from organic biomass: Process parameters and use of by-products. Appl. Energy, 144, 73-95.

15. Grootscholten, T.I.M., Kinsky dal Borgo, F., Hamelers, H.V.M., Buisman, C.J.N., 2013. Promoting chain elongation in mixed culture acidification reactors by addition of ethanol. Biomass Bioenergy, 48, 10-16.

16. Guo, X.M., Trably, E., Latrille, E., Carrere, H., Steyer, J.-P., 2014. Predictive and explicative models of fermentative hydrogen production from solid organic waste: Role of butyrate and lactate pathways. Int. J. Hydrog. Energy, 39, 7476-7485.

17. Hogg, D., Favoino, E., Nielsen, N., Thompson, J., Wood, K., Penschke, A., Papageorgiou, D., Economides, S., 2002. Economic analysis of options for managing biodegradable municipal waste, Final Report to the European Commission. Bristol, UNITED KINGDOM.

18. Kenealy, W.R., Cao, Y., Weimer, P.J., 1995. Production of caproic acid by cocultures of ruminal cellulolytic bacteria and Clostridium kluyveri grown on cellulose and ethanol. Appl. Microbiol. Biotechnol., 44, 507-513.

19. Kim, D.-H., Jang, S., Yun, Y.-M., Lee, M.-K., Moon, C., Kang, W.-S., Kwak, S.-S., Kim, M.-S., 2014. Effect of acid-pretreatment on hydrogen fermentation of food waste: Microbial community analysis by next generation sequencing. Int. J. Hydrog. Energy, 39, 16302-16309.

20. Kim, D.-H., Kim, S.-H., Kim, H.-W., Kim, M.-S., Shin, H.-S., 2011. Sewage sludge addition to food waste synergistically enhances hydrogen fermentation performance. Bioresour. Technol., 102, 8501-6.

21. Kim, D.-H., Oh, S.-E., 2011. Continuous high-solids anaerobic co-digestion of organic solid wastes under mesophilic conditions. Waste Manag., 31, 1943-1948.

22. Lim, S.-J., Choi, D.W., Lee, W.G., Kwon, S., Chang, H.N., 2000. Volatile fatty acids production from food wastes and its application to biological nutrient removal. Bioprocess Eng., 22, 543-545.

23. Lowry, O.H., 1951. Protein Measurement by Folin Reagent. J. Biol. Chem., 193, 265276.

24. Mantzouridou, F.T., Paraskevopoulou, A., Lalou, S., 2015. Yeast flavour production by solid state fermentation of orange peel waste. Biochem. Eng. J., 101, 1-8.

25. Melikoglu, M., Lin, C.S.K., Webb, C., 2013. Analysing global food waste problem: pinpointing the facts and estimating the energy content. Cent. Eur. J.Eng., 3, 157-164.

26. Moscoviz, R., Trably, E., Bernet, N., 2016. Consistent 1,3-propanediol production from glycerol in mixed culture fermentation over a wide range of $\mathrm{pH}$. Biotechnol. Biofuels, $9,32$.

27. Motte, J.-C., Trably, E., Escudié, R., Hamelin, J., Steyer, J.-P., Bernet, N., Delgenes, J.P., Dumas, C., 2013. Total solids content: a key parameter of metabolic pathways in dry anaerobic digestion. Biotechnol. Biofuels, 6, 164.

28. Motte, J.-C., Trably, E., Hamelin, J., Escudié, R., Bonnafous, A., Steyer, J.-P., Bernet, N., Delgenes, J.-P., Dumas, C., 2014. Total solid content drives hydrogen production through microbial selection during thermophilic fermentation. Bioresour. Technol., 166, 
$610-615$.

29. Motte, J.-C., Watteau, F., Escudié, R., Steyer, J.-P., Bernet, N., Delgenes, J.-P., Dumas, C., 2015. Dynamic observation of the biodegradation of lignocellulosic tissue under solid-state anaerobic conditions. Bioresour. Technol., 191, 322-326.

30. Pagliaccia, P., Gallipoli, A., Gianico, A., Montecchio, D., Braguglia, C.M., 2016. Single stage anaerobic bioconversion of food waste in mono and co-digestion with olive husks: Impact of thermal pretreatment on hydrogen and methane production. Int. J. Hydrog. Energy, 41, 905-915.

31. Pleissner, D., Lau, K.Y., Schneider, R., Venus, J., Lin, C.S.K., 2015. Fatty acid feedstock preparation and lactic acid production as integrated processes in mixed restaurant food and bakery wastes treatment. Food Res. Int., 73, 52-61.

32. Rajagopal, R., Massé, D.I., Singh, G., 2013. A critical review on inhibition of anaerobic digestion process by excess ammonia. Bioresour. Technol., 143, 632-641.

33. Shen, D., Wang, K., Yin, J., Chen, T., Yu, X., 2016. Effect of phosphoric acid as a catalyst on the hydrothermal pretreatment and acidogenic fermentation of food waste. Waste Manag. (New York, N.Y.), 51, 65-71.

34. Spirito, C.M., Richter, H., Rabaey, K., Stams, A.J.M., Angenent, L.T., 2014. Chain elongation in anaerobic reactor microbiomes to recover resources from waste. Curr. Opin. Biotechnol., 27, 115-122.

35. Sreela-or, C., Imai, T., Plangklang, P., Reungsang, A., 2011a. Optimization of key factors affecting hydrogen production from food waste by anaerobic mixed cultures. Int. J. Hydrog. Energy, 36, 14120-14133.

36. Sreela-or, C., Plangklang, P., Imai, T., Reungsang, A., 2011b. Co-digestion of food waste and sludge for hydrogen production by anaerobic mixed cultures: Statistical key factors optimization. Int. J. Hydrog. Energy, 36, 14227-14237.

37. Steinbusch, K.J.J., Hamelers, H.V.M., Plugge, C.M., Buisman, C.J.N., 2011. Biological formation of caproate and caprylate from acetate: fuel and chemical production from low grade biomass. Energy Environ. Sci., 4, 216.

38. Uçkun Kiran, E., Liu, Y., 2015. Bioethanol production from mixed food waste by an effective enzymatic pretreatment. Fuel, 159, 463-469.

39. Uçkun Kiran, E., Trzcinski, A.P., Ng, W.J., Liu, Y., 2014. Bioconversion of food waste to energy: A review. Fuel, 134, 389-399.

40. VALORGAS, 2010. D2.1: Compositional analysis of food waste from study sites in geographically distinct regions of Europe, Valorisation of food waste to biogas.

41. Venkiteshwaran, K., Milferstedt, K., Hamelin, J., Zitomer, D.H., 2016. Anaerobic digester bioaugmentation influences quasi steady state performance and microbial community. Water Res., 104, 128-136.

42. Wang, K., Yin, J., Shen, D., Li, N., 2014. Anaerobic digestion of food waste for volatile fatty acids (VFAs) production with different types of inoculum: effect of $\mathrm{pH}$. Bioresour. Technol., 161, 395-401.

43. Wang, Q., Jiang, J., Zhang, Y., Li, K., 2015. Effect of initial total solids concentration on volatile fatty acid production from food waste during anaerobic acidification. Environ. Technol., 36, 1884-1891.

44. Weimer, P.J., Nerdahl, M., Brandl, D.J., 2015. Production of medium-chain volatile 
fatty acids by mixed ruminal microorganisms is enhanced by ethanol in co-culture with Clostridium kluyveri. Bioresour. Technol., 175, 97-101.

45. Yin, J., Wang, K., Yang, Y., Shen, D., Wang, M., Mo, H., 2014. Improving production of volatile fatty acids from food waste fermentation by hydrothermal pretreatment. Bioresour. Technol., 171, 323-9.

46. Zhang, J., Wang, Q., 2013. Buffering and nutrient effects of white mud from ammoniasoda process on thermophilic hydrogen fermentation from food waste. Int. J. Hydrog. Energy, 38, 13564-13571.

47. Zhang, J., Wang, Q., Jiang, J., 2013. Lime mud from paper-making process addition to food waste synergistically enhances hydrogen fermentation performance. Int. J. Hydrog. Energy, 38, 2738-2745.

48. Zhang, Y., Banks, C.J., Heaven, S., 2012. Co-digestion of source segregated domestic food waste to improve process stability. Bioresour. Technol., 114, 168-178.

49. Zheng, J., Gao, M., Wang, Q., Wang, J., Sun, X., Chang, Q., Tashiro, Y., 2017. Enhancement of 1-lactic acid production via synergism in open co-fermentation of Sophora flavescens residues and food waste. Bioresour. Technol., 225, 159-164.

50. Zhou, P., Elbeshbishy, E., Nakhla, G., 2013. Optimization of biological hydrogen production for anaerobic co-digestion of food waste and wastewater biosolids. Bioresour. Technol., 130, 710-8.

\section{Figure and table captions}

Figure 1. Maximum hydrogen yields in the reactors according to the initial TS content (A) and the initial co-digestion ratios (B) and final $\mathrm{pH}$ values in the reactors (C)

Figure 2. Correlation circles of the final yields of VFAs (expressed as $\mathrm{g} \mathrm{COD} \cdot \mathrm{kg} \mathrm{COD}_{\text {bio }}{ }^{-1}$ ), the final $\mathrm{pH}$, the initial TS contents and the co-digestion ratios for the mono-digestion reactors (A) and the co-digestion reactors (B). They were formed by the projection in plans formed by the two first principal components, accounting for $82.6 \%$ (A) and the $76.6 \%$ (B) of the variance

Figure 3. Dual hierarchal clustering analysis of the relative abundances of the dominant bacterial OTUs (based on $97 \%$ similarity) present in the reactors after fermentation. Only the OTUs with relative abundances higher than $5 \%$ are presented

Table 1. Experimental design used in the study. All the conditions were started with $60 \mathrm{~g}$ of FW as substrate, at $35^{\circ} \mathrm{C}$ and with a S/X of $0.25 \mathrm{~g} \mathrm{VS} \cdot \mathrm{g} \mathrm{VS}^{-1}$

Table 2. Characteristics and composition of the substrates

Table 3. Total substrate conversions and final yields of products (g COD $k \mathrm{~kg} \mathrm{COD}_{\text {bio }}{ }^{-1}$ ) 

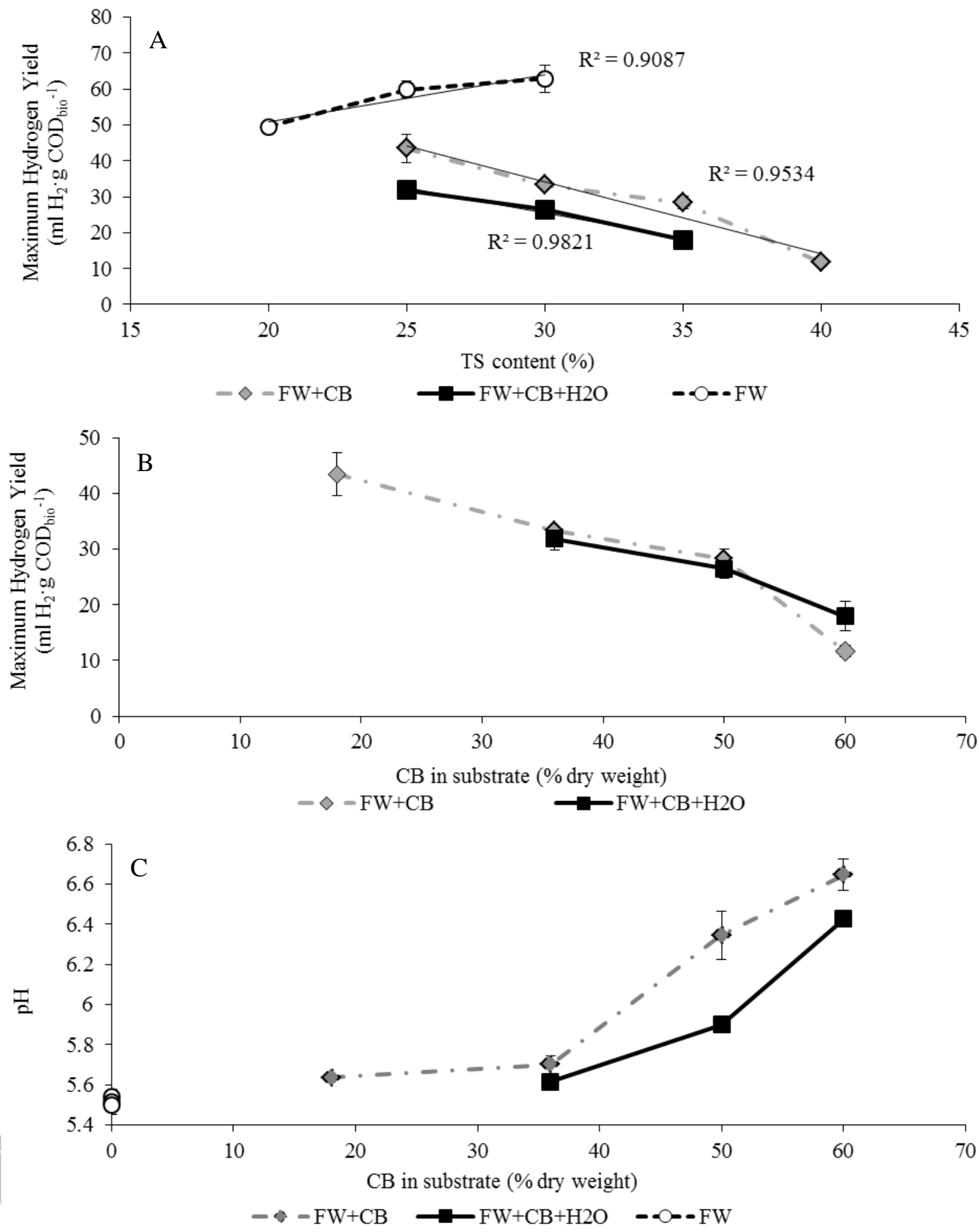

Figure 1. Maximum hydrogen yields in the reactors according to the initial TS content (A) and the initial co-digestion ratios $(\mathrm{B})$ and final $\mathrm{pH}$ values in the reactors $(\mathrm{C})$ 

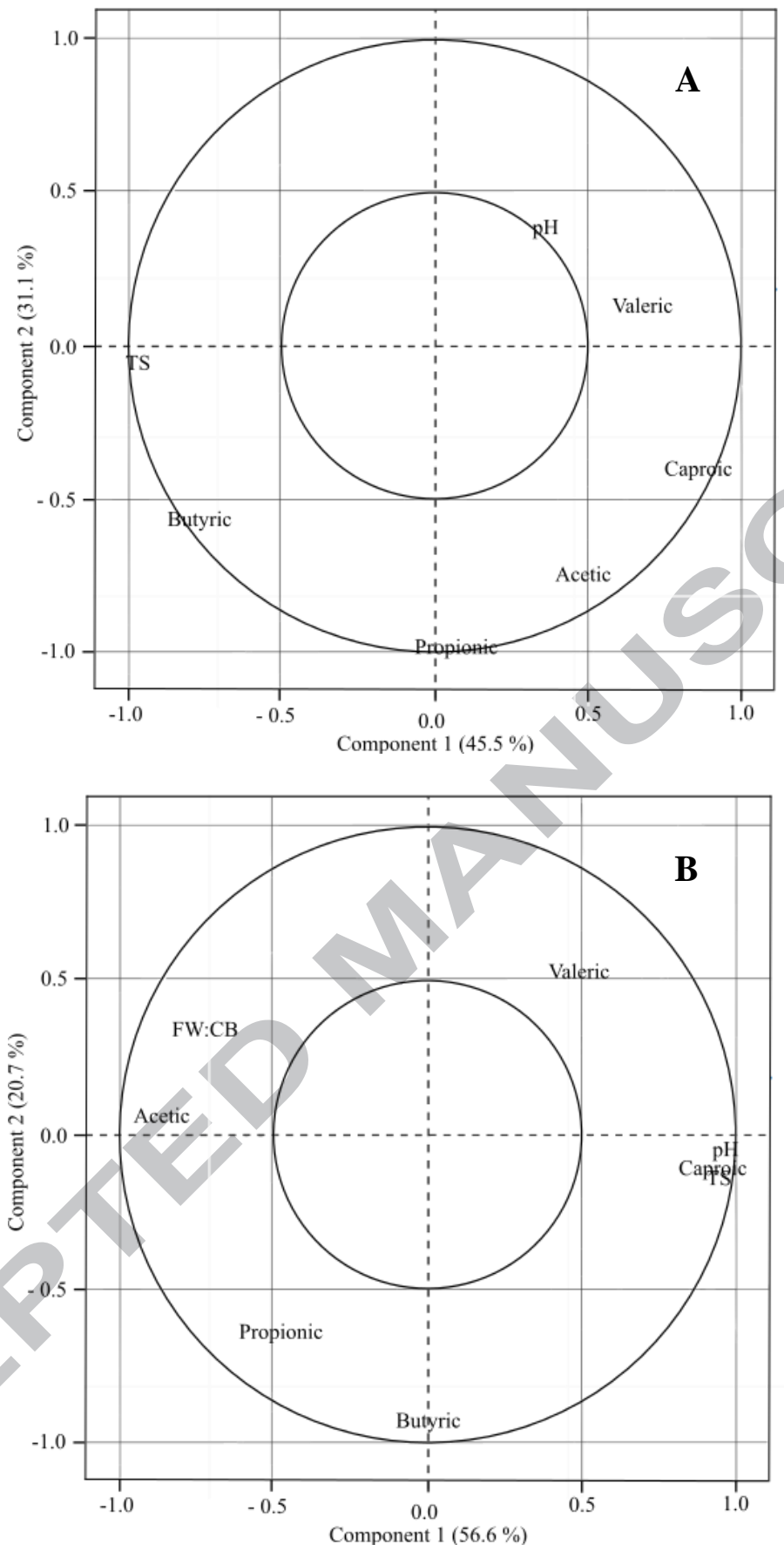

Figure 2. Correlation circles of the final yields of VFAs (expressed as $\mathrm{g} C O D \cdot \mathrm{kg} \mathrm{COD}_{\text {bio }}{ }^{-1}$ ), the final $\mathrm{pH}$, the initial TS contents and the co-digestion ratios for the mono-digestion reactors (A) and the co-digestion reactors (B). They were formed by the projection in plans formed by the two first principal components, accounting for $82.6 \%$ (A) and the $76.6 \%$ (B) of the variance 
Relative abundance
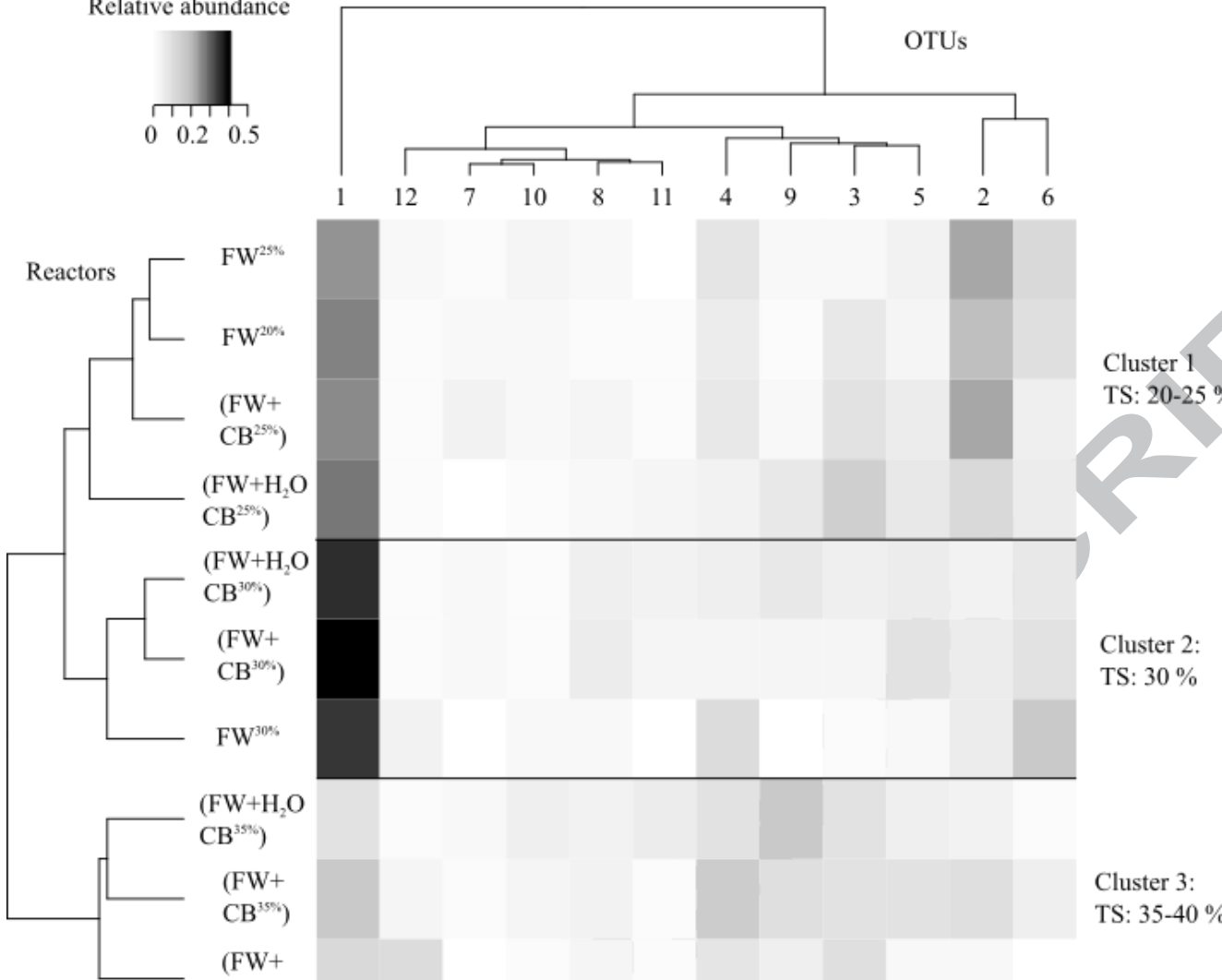

(FW+

$\mathrm{CB}^{35 \%}$ )

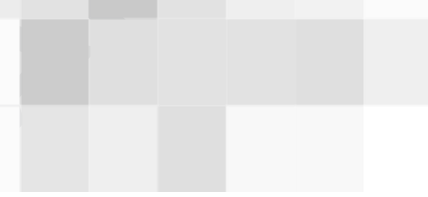

Cluster 3:

TS: $35-40 \%$

(FW+

$\mathrm{CB}^{40 \%}$ )

\begin{tabular}{|c|c|c|c|c|c|}
\hline OTU & Class & Order & Family & $\begin{array}{c}\text { Closest relative } \\
\text { affiliation }\end{array}$ & $\begin{array}{c}\text { Similarity } \\
(\%)\end{array}$ \\
\hline 1 & Clostridia & Clostridiales & Clostridiaceae_1 & $\begin{array}{c}\text { Clostridium } \\
\text { butyricum }\end{array}$ & 98 \\
\hline 2 & Clostridia & Clostridiales & Ruminococcaceae & $\begin{array}{l}\text { Neglecta } \\
\text { timonensis }\end{array}$ & 95 \\
\hline 3 & Clostridia & Clostridiales & Unclassified & $\begin{array}{c}\text { Clostridium } \\
\text { paraputrificum }\end{array}$ & 100 \\
\hline 4 & Gammaproteobacteria & Enterobacteriales & Enterobacteriaceae & $\begin{array}{c}\text { Enterobacter } \\
\text { cloacae }\end{array}$ & 100 \\
\hline \multirow[t]{4}{*}{5} & Clostridia & Clostridiales & Ruminococcaceae & $\begin{array}{l}\text { Ruminiclostridium } \\
\text { thermocellum }\end{array}$ & 89 \\
\hline & Clostridia & Clostridiales & Clostridiaceae_1 & $\begin{array}{c}\text { Clostridium } \\
\text { sporosphaeroides }\end{array}$ & 94 \\
\hline & Clostridia & Clostridiales & Clostridiaceae_1 & $\begin{array}{c}\text { Oxobacter } \\
\text { pfennigii }\end{array}$ & 92 \\
\hline & Clostridia & Clostridiales & Unclassified & $\begin{array}{c}\text { Acutalibacter } \\
\text { muris }\end{array}$ & 94 \\
\hline 9 & Clostridia & Clostridiales & Ruminococcaceae & $\begin{array}{l}\text { Lascolabacillus } \\
\text { massiliensis }\end{array}$ & 91 \\
\hline 10 & Clostridia & Clostridiales & Ruminococcaceae & $\begin{array}{c}\text { Clostridium } \\
\text { cellulosi }\end{array}$ & 93 \\
\hline 11 & Clostridia & Clostridiales & Ruminococcaceae & $\begin{array}{l}\text { Clostridium } \\
\text { carnis }\end{array}$ & 99 \\
\hline 12 & Clostridia & Clostridiales & Ruminococcaceae & $\begin{array}{c}\text { Dethiobacter } \\
\text { alkaliphilus }\end{array}$ & 89 \\
\hline
\end{tabular}

Figure 3. Dual hierarchal clustering analysis of the relative abundances of the dominant bacterial OTUs (based on $97 \%$ similarity) present in the reactors after fermentation. Only the OTUs with relative abundances higher than $5 \%$ are presented 
Table 1. Experimental design used in the study. All the conditions were started with $60 \mathrm{~g}$ of

FW as substrate, at $35^{\circ} \mathrm{C}$ and with a S/X of $0.25 \mathrm{~g} \mathrm{VS} \cdot \mathrm{g} \mathrm{VS}^{-1}$

\begin{tabular}{|c|c|c|c|c|c|}
\hline Reactor number & Objective & $\begin{array}{l}\text { Substrate TS } \\
\text { content }(\%)\end{array}$ & $\begin{array}{l}\text { CB in substrate } \\
\text { (\% dry basis) }\end{array}$ & $\begin{array}{l}\text { Initial substrate } \\
\text { concentration } \\
\left(\mathrm{g} \mathrm{COD}_{\mathrm{bio}} \cdot \mathrm{kg}^{-1}\right)\end{array}$ & $\begin{array}{c}\text { Initial FW } \\
\text { concentration } \\
\left(\mathrm{g} \text { VS } \cdot \mathbf{l}^{-1}\right)\end{array}$ \\
\hline $\mathrm{FW}^{20 \%}$ & \multirow{3}{*}{$\begin{array}{l}\text { FW fermentation at } \\
\text { increasing TS contents }\end{array}$} & 20 & - & 42.5 & 29.9 \\
\hline $\mathrm{FW}^{25 \%}$ & & 25 & - & 53.2 & \\
\hline $\mathrm{FW}^{30 \%}$ & & 30 & - & 64.0 & 45.0 \\
\hline$(\mathrm{FW}+\mathrm{CB})^{25 \%}$ & \multirow{4}{*}{$\begin{array}{l}\text { Adjustment of the TS } \\
\text { content of the substrate } \\
\text { by CB addition }\end{array}$} & 25 & 18 & 48.5 & 31.7 \\
\hline$(\mathrm{FW}+\mathrm{CB})^{30 \%}$ & & 30 & 36 & 52.0 & 30.3 \\
\hline$(\mathrm{FW}+\mathrm{CB})^{35 \%}$ & & 35 & 50 & 55.3 & 28.6 \\
\hline$(\mathrm{FW}+\mathrm{CB})^{40 \%}$ & & 40 & 60 & 58.3 & 26.7 \\
\hline$\left(\mathrm{FW}+\mathrm{CB}+\mathrm{H}_{2} \mathrm{O}\right)^{25 \%}$ & \multirow{3}{*}{$\begin{array}{l}\text { Complementary reactors } \\
\text { (same substrate } \\
\text { composition that previous } \\
\text { at lower initial TS } \\
\text { content) }\end{array}$} & 25 & 36 & 43.4 & 25.3 \\
\hline$\left(\mathrm{FW}+\mathrm{CB}+\mathrm{H}_{2} \mathrm{O}\right)^{30 \%}$ & & 30 & 50 & 47.4 & 24.5 \\
\hline$\left(\mathrm{FW}+\mathrm{CB}+\mathrm{H}_{2} \mathrm{O}\right)^{35 \%}$ & & 35 & 60 & 50.9 & 23.3 \\
\hline
\end{tabular}


Table 2. Characteristics and composition of the substrates

\begin{tabular}{cccc}
\hline Parameter/Element & Unit & Model Food Waste & Cardboard \\
\hline TS & $\%(\mathrm{w} . \mathrm{b})$. & $21.6 \pm 0.7$ & $92.7 \pm 3.7$ \\
VS & $\%$ TS & $96.1 \pm 0.1$ & $77.6 \pm 0.2$ \\
pH & Unit pH & 5.60 & 7.10 \\
COD & $\mathrm{g} \mathrm{COD} \cdot \mathrm{g} \mathrm{TS}^{-1}$ & $1.37 \pm 0.05$ & $1.19 \pm 0.05$ \\
Carbohydrates & $\mathrm{g} \cdot \mathrm{kg} \mathrm{TS}^{-1}$ & $687 \pm 15$ & $958 \pm 5$ \\
Proteins & $\mathrm{g} \cdot \mathrm{kg} \mathrm{TS}^{-1}$ & $169 \pm 10$ & 0 \\
Lipids & $\mathrm{g} \cdot \mathrm{kg} \mathrm{TS}^{-1}$ & $72.3 \pm 1.5$ & 0 \\
TKN & $\mathrm{g} \cdot \mathrm{kg} \mathrm{TS}^{-1}$ & $27.1 \pm 1.6$ & $2.00 \pm 0.02$ \\
TC & $\mathrm{g} \cdot \mathrm{kg} \mathrm{TS}^{-1}$ & $441 \pm 6$ & $366 \pm 6$ \\
C/N & - & 16.3 & 183.0
\end{tabular}


Table 3. Total substrate conversions and final yields of products ( $\mathrm{g}$ COD $\cdot \mathrm{kg} \mathrm{COD}_{\text {bio }}{ }^{-1}$ )

\begin{tabular}{cccccccc}
\hline Reactor & $\begin{array}{c}\text { Substrate } \\
\text { Conversion }\end{array}$ & Acetic acid & $\begin{array}{c}\text { Butyric } \\
\text { acid }\end{array}$ & $\begin{array}{c}\text { Propionic } \\
\text { acid }\end{array}$ & $\begin{array}{c}\text { Valeric } \\
\text { acid }\end{array}$ & $\begin{array}{c}\text { Caproic } \\
\text { acid }\end{array}$ & Hydrogen \\
\hline $\mathrm{FW}^{20 \%}$ & $627 \pm 3.0$ & $248 \pm 16$ & $224 \pm 11$ & $25.4 \pm 0.5$ & $33.5 \pm 4.4$ & $60.4 \pm 5.2$ & $35.3 \pm 0.2$ \\
$\mathrm{FW}^{25 \%}$ & $631 \pm 1.8$ & $237 \pm 4$ & $235 \pm 0$ & $25.8 \pm 3.0$ & $32.3 \pm 5.6$ & $57.8 \pm 8.7$ & $42.7 \pm 1.6$ \\
$\mathrm{FW}^{30 \%}$ & $620 \pm 0.0$ & $238 \pm 0$ & $238 \pm 0$ & $25.4 \pm 0.1$ & $28.7 \pm 0.2$ & $42.8 \pm 0.0$ & $46.9 \pm 0.2$ \\
\hline$(\mathrm{FW}+\mathrm{CB})^{25 \%}$ & $622 \pm 0.9$ & $264 \pm 1.0$ & $239 \pm 10$ & $27.3 \pm 0.5$ & $19.6 \pm 0.1$ & $40.4 \pm 2.3$ & $31.0 \pm 2.7$ \\
$(\mathrm{FW}+\mathrm{CB})^{30 \%}$ & $647 \pm 0.1$ & $280 \pm 3.0$ & $245 \pm 4$ & $26.6 \pm 0.7$ & $20.5 \pm 1.7$ & $51.0 \pm 0.1$ & $23.8 \pm 0.0$ \\
$(\mathrm{FW}+\mathrm{CB})^{35 \%}$ & $616 \pm 0.4$ & $245 \pm 5$ & $237 \pm 2$ & $26.1 \pm 2.7$ & $24.0 \pm 0.0$ & $63.5 \pm 9.2$ & $20.2 \pm 1.3$ \\
$(\mathrm{FW}+\mathrm{CB})^{40 \%}$ & $565 \pm 1.0$ & $181 \pm 8$ & $242 \pm 13$ & $25.8 \pm 1.0$ & $38.5 \pm 5.3$ & $70.1 \pm 5.7$ & $8.3 \pm 0.7$ \\
\hline$\left(\mathrm{FW}+\mathrm{CB}+\mathrm{H}_{2} \mathrm{O}\right)^{25 \%}$ & $698 \pm 0.6$ & $329 \pm 3$ & $234 \pm 3$ & $27.4 \pm 1.2$ & $25.6 \pm 7.1$ & $49.1 \pm 1.1$ & $22.7 \pm 1.4$ \\
$\left(\mathrm{FW}+\mathrm{CB}+\mathrm{H}_{2} \mathrm{O}\right)^{30 \%}$ & $675 \pm 1.0$ & $278 \pm 5$ & $275 \pm 11$ & $28.2 \pm 0.1$ & $20.2 \pm 1.0$ & $53.9 \pm 4.1$ & $18.9 \pm 1.2$ \\
$\left(\mathrm{FW}+\mathrm{CB}+\mathrm{H}_{2} \mathrm{O}\right)^{35 \%}$ & $603 \pm 1.5$ & $212 \pm 7$ & $255 \pm 9$ & $27.7 \pm 0.5$ & $25.2 \pm 0.2$ & $69.6 \pm 2.2$ & $12.8 \pm 1.9$ \\
\hline
\end{tabular}




\section{Graphical abstract}

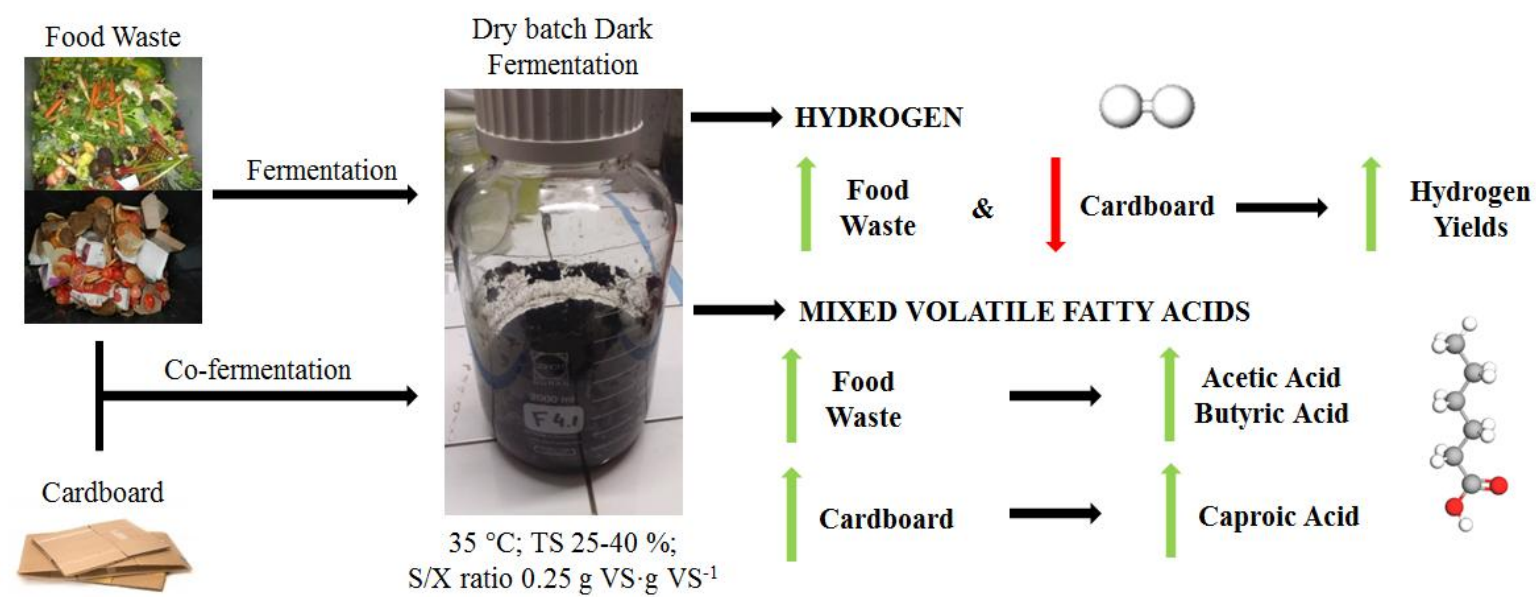




\section{Highlights}

- Hydrogen yields affected negatively by CB addition and positively by TS content

- Higher yields of caproic acid at higher proportions of $\mathrm{CB}$

- Caproic acid produced by consumption of hydrogen and acetic acid

- Metabolite production driven by metabolic changes within the same microbial species 